\title{
THE EFFECT OF ROMANTIC CARTOON MOVIE TO CHILDREN UNDER AGE GROWING (STUDY ON THE IMPLICATION MOVIE)
}

\author{
Maryam M. Lughu
}

\begin{abstract}
The purpose of the writing is to find out the effect in watching romantic movie to the children under age growing and the way to handle the problem which categorized dangerous in case the children mingle tightly with any types of gadgets and get the computer lesson from school. This process uses qualitative approach. The data is taken based on the data from books, article or information from newspaper that uses six steps. There are organizing and preparing, reading, coding, describing, advancing and evaluating. The meaning of learning theoretically and practically is expected that the result of the learning can give contribution to special department such as ICPD (Indonesian children protection department) or in Indonesian it is called KPAI. Beside that, it is expected that the result can help the reader or learner in learning the way in handling problems related to the children under age growing. In this part, it is determined not to reveal the flaws or talk about people's mistakes but it tends to the handling process of children under age in modern area.
\end{abstract}

Keywords : Cartoon Movie, Romantic, Children Under Age, Soul Growing, Effect

\section{INTRODUCTION}

Rene Welleck and Austin Warren in their book "Theory of Literature" said that "Literature represents life and life is in large measure a social reality, even though the natural world and the inner or subjective world of the individual have also been objects of literary imitation". It is described that literature displays the human's life. It is a mirror of life. Through literary work, people can see their own or even other people' life through the story. It is significant to learn literature because we can get pleasure, life lesson and moral message. The literary work consists of novel, drama, short story, poetry, film or movie. Movie as a part of literary teaches people many things such as the life lesson through plot, the characterization from many different people, the setting through place, time (which is consists of history) or even the fashion. 
Movie is a series of still images on a strip of plastic which, when run projector and shown on a screen, creates the illusion of moving images. (http: //en.m.wikiquote.org/wiki/ film). From this definition, It is revealed that by watching movie, people can get pleasure when the movie itself is exciting, get knowledge about the life lesson especially learning many characteristics (such as kind, rude, lazy, smart, good looking, patient, bad, stupid, gentle, ugly, etc), people also can learn how to recognize other people' characteristics especially how the way they interact with different people with different characteristics.

Movie has many types. One of the types is cartoon. A cartoon is a form of two -dimensional illustrated visual art. A cartoon (from Italian : Cartone and Dutch : Karton - words describing strong, heavy paper or pasteboard) is a full-size drawing made on sturdy paper as a sturdy paper as a study or modello for a painting, stained glass or tapestry. Cartoons were typically used in the production of frescoes. To accurately link the components parts of the composition when painted on damp plaster over a series of days. (http: //en.m.wikiquote.org/wiki/film). Many kinds of cartoon movie are published to the public and had been watched by any children out there. One thing that has forgotten by any educators or parents here is about the plot of the movie. Talking about romantic movie is definitely known and seen by a lot of children without being recognized by the adult that the programs had been damage the children's brain. There are some adult actions that could not be watched by children under age had been seen clearly such as lip kissing, deep holding or other adult action in bed. Cartoon movie is a media which portray the audiovisual and moving message. Therefore, movie gives impressive impression for the watchers. The cartoon movie is liked generally by the children because of interesting animated pictures character. Based on the explanation above, it can be explained that seeing and listening directly to the media is able to motivate the children to learn quickly, gives pleasure, raise passion to understand fast and imitate of the story.

The ideal of romantic love has existed for centuries within the realm of Western culture. In fact, the word romance dates back to the 12th century when stories about love were disseminated by troubadours in France (Stone, 1988). The word Romans is French for - stories\| and is the foundation for the word romance because it was first coupled with literature about courtly love (Stone, 1988). Today, the pairing of romance with stories continues to be a popular part of entertainment culture. The Oxford English Dictionary (1989) defines Romance with descriptions such as, - that class of literature which consists of love stories\| and -idealistic character or quality in a love affair. This definition suggests that the very essence of romance necessarily includes an element of fantastical invention or unrealistic love. The implication is that the term - romantic ideall is redundant, as all romance can be defined as ideal in some form. romantic ideals is a more comprehensive conceptualization, as it is a collection of expectations about relationships and love that 
extends beyond individual partners. Because the romantic storylines are often secondary plots in such films, they seldom contain the repeated tests and challenges that are central to the storyline in romantic comedies. In a sense, other films that contain ideals may offer a more potent, undiluted message about romance. One recent content analysis documented that roughly $80 \%$ of romantic relationships portrayed in Disney films have love-at-firstsight beginnings (Tanner et al., 2003). For example, in Snow White (1937), the handsome prince falls instantly in love with Snow White after he awakens her from a magical sleep. Thus, young people may be exposed to romantic ideals from a variety of movies, even those watched at an early age.

Seeing a lot of phenomenon, it is definitely can be indicated that the children unconsciously can imitate the actions in the movie both verbally (statement, dialog and quotations) and non verbally (body language) especially without the parents' control. (Amini, 2008). In 2011, it is reported based on the data from children magazine 'Kidia', Iran noted that 15 to $20 \%$ children who have bad attitude as the effect of cartoon movie, such as being aggressive, rude, selfish and the worst thing here is the time to watch movie is longer than time to study the lesson from school (Amini, 2008). Through this explanation, it is definitely clearly stated that even though cartoon movie but the parents should be careful in choosing the choices because the children can imitate the story through the words and gestures. It can be imagined that when they listen to words or see things that is forbidden to their age, they will do such a thing like kissing or saying adult words. Their psychology will grow up fast, they will speak and act like the adult.

On child psychology, children's films leave a pronounced footprint today on the personalities and development of a child's emotional, cognitive and social development. It is important to note that a passive lifestyle that consists of spending large amounts of time watching movies and television can influence a child's thoughts and behaviors. If a child sees violent, sexual and/or unrealistic child-based movies and cartoons, he or she ay internalize these images in school or at home. Belief systems in children and teens are also influenced by movies, especially in the absence of an already established belief system. Many times, present day, child-based movies and cartoons are based on an element of aggression, which counteracts what the children might learn in school or at home. It is the extreme or constant attachment with television and movies that can lend itself well to depression, in particular, as well as other mental health issues. Not that it is necessarily causal - though it can be in some instances - but it can be one contributing factor among several. Sexual adults create children's movies, so if a little sexual innuendo finds itself in a Sponge Bob movie for children or a Dream works ids flick, it should not be surprising. Child-based movies and cartoons not only leave a lasting impression on the minds of children, they also influence children's behaviors. Child-based movies are more powerful than most television sitcoms or 
TV shows for children. It is because there is more time to develop characters and influence thought processes than with thirty minutes television sitcoms. Because the characters are more developed, people tend to become more emotionally bonded to the characters and storylines. Children's movies from years ago also exhibited well-developed characters and those characters tended to have a deeper emotional significance to the viewer.

Recently, Indonesian children under age growing is contaminated by modern development related to social relations which categorized is in dangerous zone in case of watching movie. Based on the result of so many news investigations and observations, children under age growing now can be said as the worst moment. Handayani (2006) does research to several cartoon movies such as Naruto, Spongebob, Avatar, Pokemon. The result points out that cartoon movies have many anti-social or violence $68,4 \%$ than pro to social $31,6 \%$. It is opposite with the heroic theme of the movie. This study reveals that the category of anti social treatments appear more often are telling rude words $22,56 \%$, bring misfortune to life $30,46 \%$ and humiliation $15,43 \%$. For the pro-social category, it tends to picture the treatment of the warmth is $9,16 \%$, politeness $7,05 \%$, empathy $8,33 \%$ and advice is 7,06\%. Indonesian Children Protection Department (ICPD) or in Indonesia, Komisi Perlindungan Anak Indonesia (KPAI) reported that 20 to $30 \%$ of television programs especially cartoon movie affect the children's growing badly and direct them to do negative things. The example is Cartoon movie 'Sinchan' from Japan which is the main character, Sinchan always acts rude and his negative attitude refers to sex problems. (KPAI, 2008). Seeing this percentage, it need a personal effort to protect the children because the children are the future generation of the country. One can influence another by mingling the relation through social relation. Every parent wants their children grow up well, not being broken at their children moment. It is a hope from everyone because it is certainly happiness is the target of life.

Maccoby states “There is reason to believe that children's attitudes and beliefs can be shaped by what they see on television, and that emotions and impulses are aroused in the child viewer to-match those portrayed by screen characters. From this words, it is depicted clearly that the children is easier to learn something just by seeing and listening something even though sometimes they can not differ which one is suitable for them and which one is not. Learning this situation, the writer tries to present the arguments about the situation based on the cause and effect because as we know that the children is the next generation of a nation. A great nation will be developed well if it has great next generation.

The reason why does the writer choose this topic is because there are lots of children become victim because of lack of knowledge and uncontrolled life whether it is because of parents, teacher, friends, social and religion department, social relation or other causes. 
Based on these problems, it is seen that children under age have lost controlled and therefore need to be protected, controlled and handled wisely.

The purpose of this writing is to find out which cartoon movies that reveal the forbidden words for children to be used (being romantic like adult), the effect in watching romantic movie to the children under age growing and the way to handle the problem which categorized dangerous in case the children mingle tightly with any types of gadgets and get the computer lesson from school.

\section{METHODOLOGY}

This research is classified as a Qualitative research. According to Bogdan and Bikklen, Qualitative research is descriptive. The data collected are in the form of words or pictures rather than numbers. The result contains quotations from data to illustrate and substantiate the presentation (1982:30). The data are taken from the data, articles, books or references which reveal the related information about the writing. It aims to support the writing. The data collectied are in the forms of words quotations, definitions or statements or pictures, analysis, process and participants' meaning. There are six steps used as a process of analysis namely organizing and preparing, reading, coding, describing, advancing and evaluating.

\section{FINDING AND DISCUSSION}

\section{The List of Cartoon Movies}

Here are some romantic cartoon movies which have a lot of effect to the children under age especially in imitating the adult action with the pictures and some dialogs or words that support the context. There are : Snow White, Little Mermaid, Mulan, Pocahontas, Sinchan, Beauty and the Beast, Tangled, Cinderella, Princess and the Frog, the Swan Princess, Shrek, Aladin.

\section{a. Snow White}

Snow white takes on the mother role in the film, we see her doing domestic tasks such as cooking, cleaning, washing, and taking care of the seven dwarfs. She does this all while smiling and singing or humming along. Snow White does all these things without complaining at all. It conveys what "proper" gender roles of the time were, being released in 1937. The plot tells about the queen with her magic mirror who feels jealous to snow white because she has the fairest face. The negative thought rises in the queen's mind to kill snow white by poisoning snow white so that nobody will defeat her beauty. The snow white is not died but just sleep. A charming prince come to rescue her by giving her a truest kiss. 


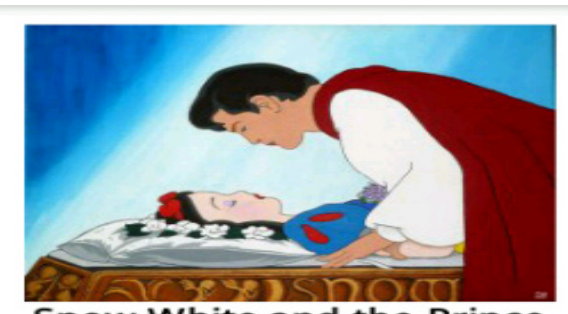

Snow White and the Prince

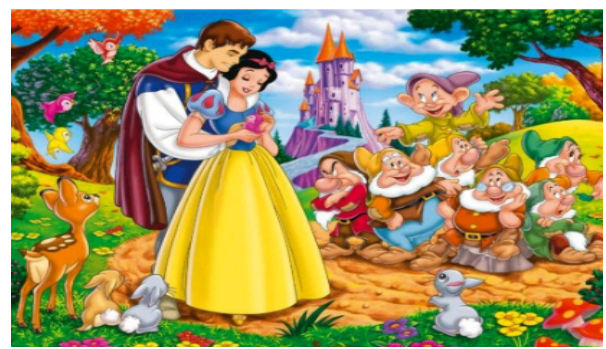

"One day, Prince Charming was going past the cottage and he saw snow white lying in the coffin. He said to the dwarfs, My! My! She is so beautiful! I would like to kiss her! And he did. Immediately, snow white opened her eyes. She was live again! the prince and the seven dwarfs were very happy. Prince charming married snow white and took her to his palace and lived happily ever after

b. The Little Mermaid

In "The Little Mermaid," Ariel, the mermaid, exemplified the stereotypical passive female role. At the first glimpse, it seems that Disney did not pay much attention to the Women's Movement. For example, Ariel is the same as the earlier Disney heroines, except that she is sexy and wears a bikini made from shells. Also, everything she is interested seems to be all about getting her lover, the prince. As shown in the animation, Ariel seems to be willing to do anything in order to make the prince fall in love with her. She even gives up her voice so that she can have legs, which can make her look better in front of the prince. Even though the animation has happy endings, and Ariel gets her voice back and keeps her lover, she has to leave behind her home, family, and friends. This shows that she, a female character, gives up everything for her love. This ends up with happy endings. However, Ariel who gives up everything including her family and career just for her romance would have somewhat negative influence on young girls who have to study and think about their careers in the future.

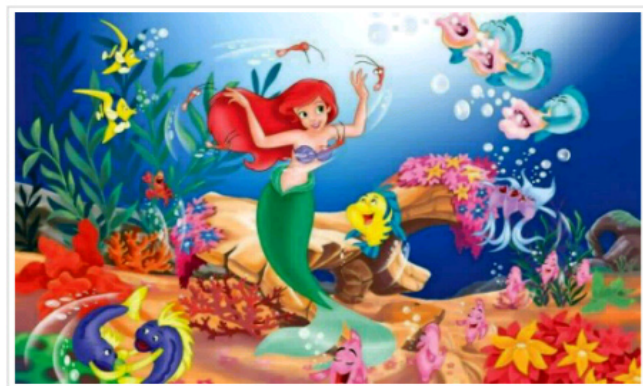

- $\quad$ Wedding ship

The ceremony is continuing..

Minister : (to Eric..) as long as you both shall live?

Eric : (Eric hesitates. The maiden looks in his eyes, compelling him) I do

Maiden : (with just a hint of arrogance) I do!

(Eric and Ariel kiss on their wedding) 


\section{c. Mulan}

After spending a lot of time on how Disney princesses lack independence, it is important to look at how history has brought upon the more independent Disney female character, and what not a better way than to look at one of their most independent character - Mulan. Mulan is a more contemporary character in Disney animation and is based on a true story. It is said best when she is described as braver, more independent, and less focused on finding a husband than other female Disney characters.(Disney Archives) Unlike some of the previous animated films, Mulan transforms herself into a man in order to enter the army in her ailing father's place. She cuts her hair and dresses as a man and through discipline and determination is able to become one of the best soldiers in the army. Mulan did not wait for a man to come to her rescue, but instead, became the rescuer herself. For another view of a more modern Disney Princess please check out Andy Klein's article, "Disney's Mulan: A More Modern Heroine," written for Animation.

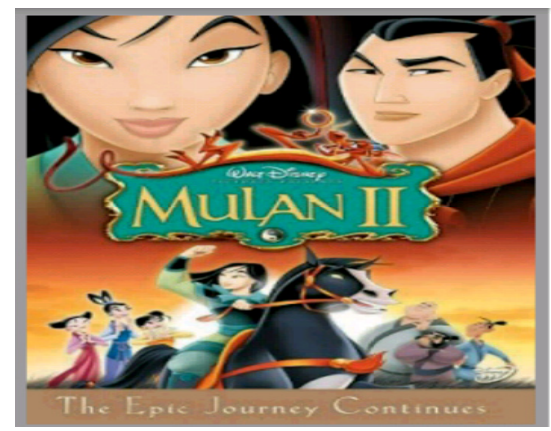

\section{d. Pocahontas}

In Pocahontas, Pocahontas is almost invariably being raised by a single father with no sign or mention of a mother or mother figure, ever. The heroine's motherless life serves to accentuate her own feminine virtues and independence, since her father is invariably domineering, feeble, and/or ridiculous. Also, there is no "competing" feminine figure to suggest that the heroine needs any support or guidance. The female character, Pocahontas, shows that her potential as a leader is complicated by her position on the margins of tribal life. When she meets and falls in love with John Smith in the forest, she is forced to keep the encounter secret, giving her pleas that the white men can be reasoned with little weight. Her secrecy indirectly causes the death of Kocoum at the hands of one of Smith's friends, thus leading her tribe and the English to the brink of war. Her courageous act of shielding Smith from her father's club with her body, however, is an act of self-sacrifice, and she does it knowing she risks further alienation from her tribe. Pocahontas thus serves as an example of a female character with a more important role in Disney movies. In the Disney's early age animations, female characters with minor or even inferior roles didn't really give a good message to young girls today, in the 21 st century. However, as gender roles have 
changed, the female characters in Disney animations have also changed with gaining more importance in their roles.

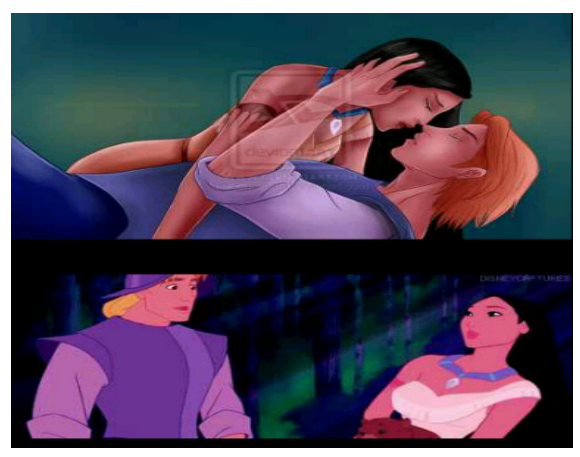

\section{e. Beauty and the Beast}

This movie has been introduced under the Disney banner of productions. It is loved by the children as well as adults. It is romantic film story between a beast and a beautiful lady. Belle, whose father is detained by the Beast, offers herself rather and identifies her captor to be a captivated sovereign. The story is phenomenal and remarkable and dissolves your heart lice a fiery breakout.
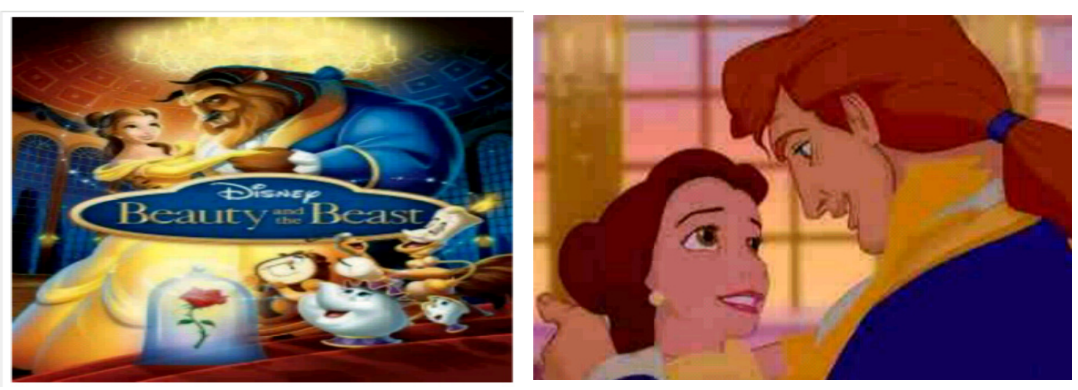

\section{f. Tangled}

The mystically since a long time ago haired Rapunzel has used her whole life in a tower, however now that a runaway criminal has discovered her, she is going to uncover the planet to many people's surprise, and who she truly is.

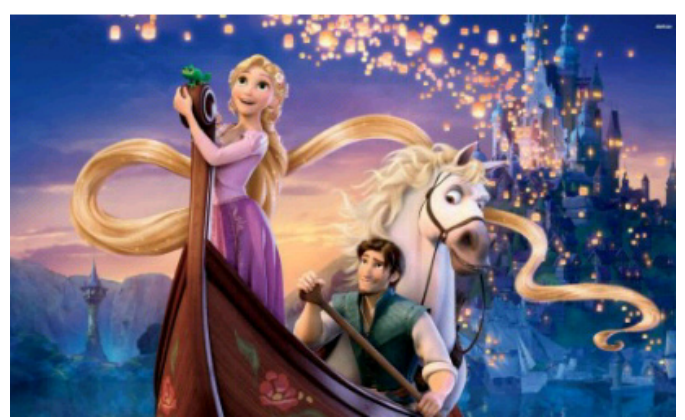




\section{g. Cinderella}

She lives with her father, stepmother and two stepsisters who are so rude and displays disrespect treatment. A true love felt by her from a prince who finds her glass shoes at the palace where there is a dance party. She finds her happiness through a very kind godmother who direct her to find her true love. Unhappy feeling becomes happy when they get marry and live in the palace.
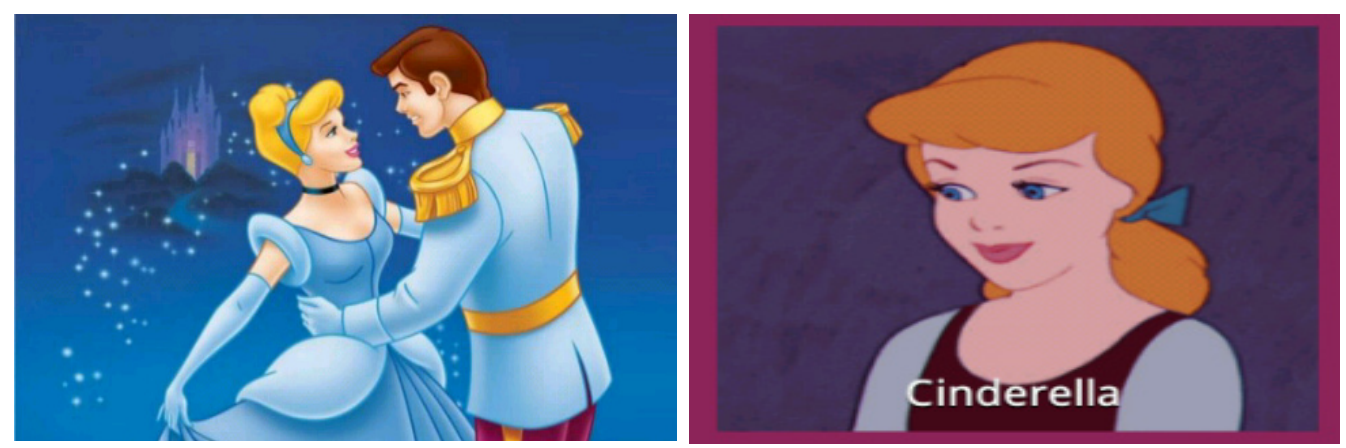

h. Princess and the Frog

A fairy tale set in Jazz Age era New Orleans and centered on a young woman named Tiana and her fateful kiss with a frog prince who desperately wants to be human again. Tiana and Naveen reveal their love to each other and explain the situation to Charlotte who agree to kiss Naveen. The clock strikes midnight before she can kiss him, but the two decide they are content to live together as frogs. Because of Tiana's new status as princess, they are restored back to human form after they kiss. The couple return to New Orleans to celebrate and Tiana and Naveen open the new restaurant.
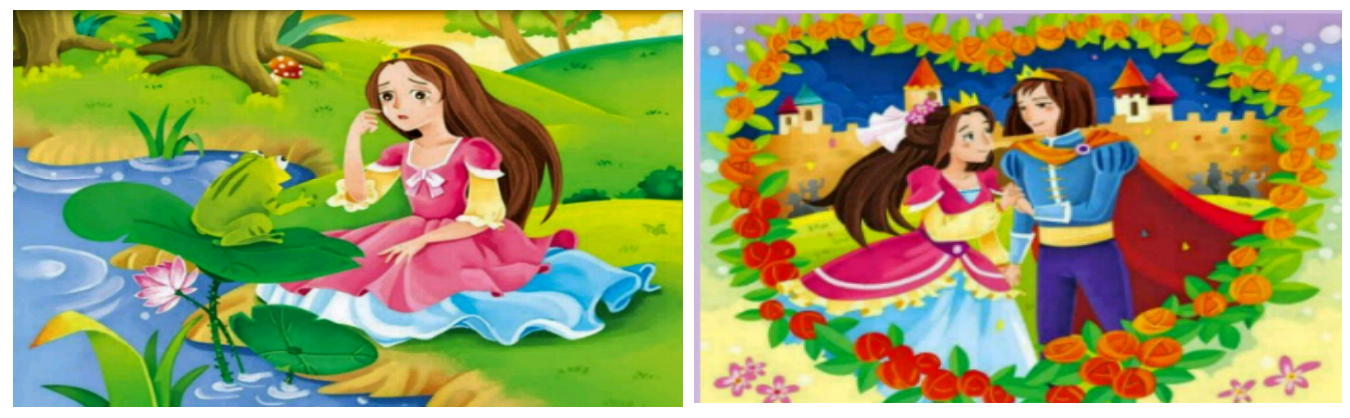

i. The Swan Princess

A force ravenous magician converts a princess into a swan by day in this story of everlasting love. A love of triangle which finally lead to the real love. Derek confesses to Odette that he loves her for her kindness and courage and Odette returns to life, the spell on her broken. The two are married and live happily ever after. 


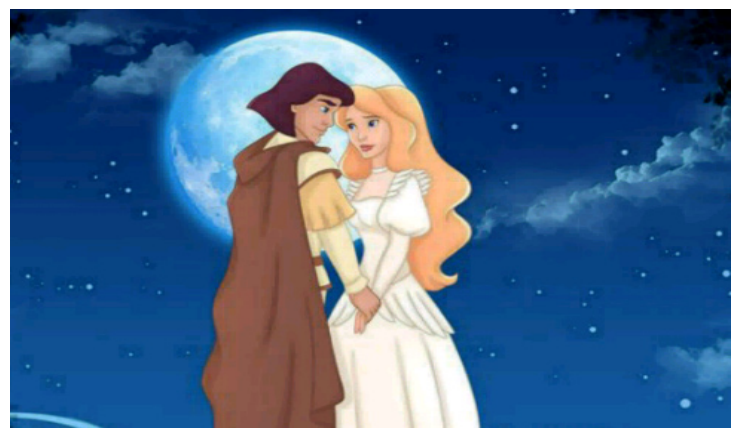

j. Shrek

An Ogre, in order to regain his swamp, travels along with an annoying donkey in order to bring a princess to a scheming lord, wishing himself King. A struggle for getting the true love. Shrek interrupts the wedding before Farquaad can kiss Fiona. He tell her that Farquaad is not her true love and only marrying her to become King. Shrek and Fiona profess their love and share a kiss, they marry in the swamp and leave on their honeymoon while the rest celebrate by singing 'I am a believer'
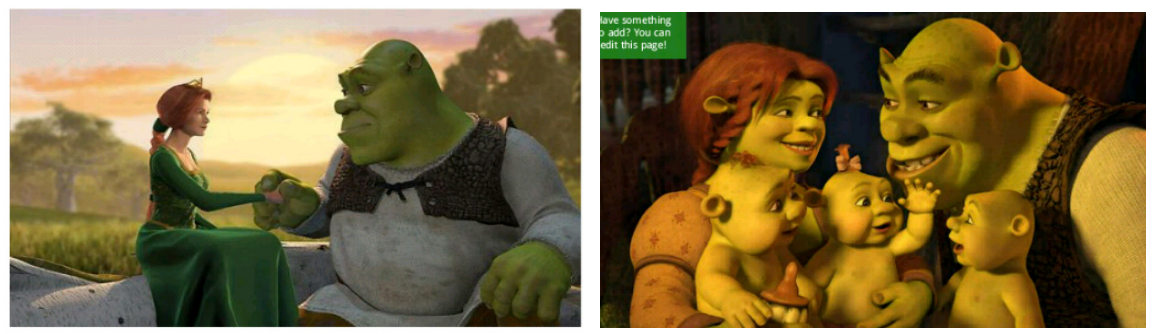

h. Aladdin

Aladdin, a road urchin, unintentionally meets Princess Jasmine, who is in the city undercover. They adore one another, yet she can just wed a prince. After discovering Jasmine's love for Aladdin, the Sultan changes the law to allow her to marry whomever she deems worthy. The newly free Genie leaves to explore the world while Aladdin and Jasmine celebrate their engagement.

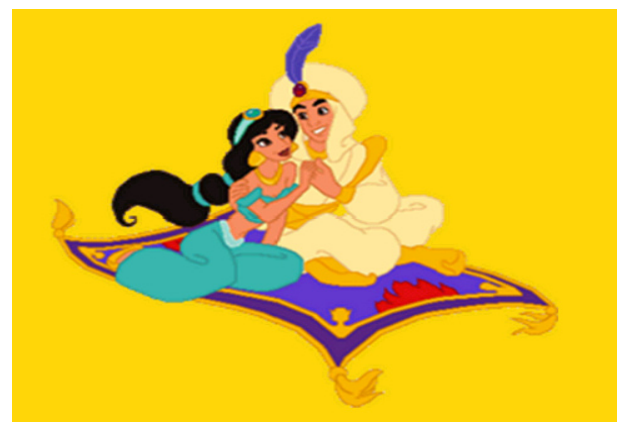




\section{The Effect of The Movie with The Solving Problem}

Those movies above are representatives of cartoon movies that can stimulate the children under age mind to do negative things such as they know how to hug, how to kiss even probably by the experience that they see surround them, they will gain the information from adult about what is love, why they hug and kiss and about the marriage (arranged marriage), they will speak and act like adult words and actions because even though those are cartoon movies but those tell about adult's life relationship. By seeing them, they will also imitate not only verbally but also non verbally. The children will imitate the way how to hug their friend, how to kiss, they will act as a bride and the bridegroom even will say inappropriate words such as, I love you, I miss you or will you marry me? Or other words. From the examples of the movies above, adults are directed to be more pay attention to what program do the children watch especially movies even though those are cartoons but the context within the movie should be the first attention from the parents. By the words or actions showed up by the movies reveal a lot of life teaching especially Disney movies, the parents should check first so that their children will not be wrong in watching the movies because through internet the children can access the original without being filtered by the Indonesian government.

After finding the evidences, it is definitely shown that Literature gives bad effect to children if it is not controlled well by the parents or educators. The psychologist, Jerone Brunner's statement states that learning through media can stimulate great passion. It is clarified that while watching the movie, the children learn about the characters and also the plot of the story and imply that in the real situation of their life. In other word, the children imitate the movie and practice it with people surround them moreover if they are interested and the movie is interesting without thinking whether it is suitable with their age or not. The leading point for them is just their passion and their interest to the movie.

What should parents focus on when selecting television movies, cartoons and sitcoms for their children? Since television and movies are a reality what can parents and teachers do? The best thing that educators and parents can do is monitor what children watch on television. Take an interest in the viewing preferences of children, set guidelines on how long they can watch movies, cartoons and television sitcoms and monitor what types of shows they watch.

Parents can help their children to avoid programs that are too frightening, which show that television or films may contribute to a case of mental illness, when the condition exists. What television will contribute depends, then, on the situation, as well as on television content, and the situation depends largely on the personality and environment of the child. It points out that most children in a reasonably stable environment, do not confuse the makebelieve world of television with the real experiences of personal and family relationships. 
In general, the evidence on physical effects is negative. Television postpones average bedtimes a few minutes, but seems to decrease sleeping time very little because children who have stayed up later appear to go to sleep more quickly. It is true that there are reports in the research of children who are frightened by evening television and unable to go to sleep, and of children who are sleepy in school because they have stayed up late at night to see a program, but none of the studies can find any evidence of widespread fatigue or other physical effect related to television. To sum up briefly, the findings that movies were indeed having significant effects on children and they remembered a great deal from them. Children's attitudes were frequently changed by films, and this attitude change was often cumulative - hardly noticeable after a single exposure, but gathering strength and depth with repeated exposure to pictures of a given kind. It was found also that movies often roused strong emotional reactions in children, and that if and until "adult discount" was developed the movies often "took possession" emotionally of these children. Finally, it was found that movies do influence children's behaviour, notably their play. When a group of delinquents was studied, it was found that they went to the movies oftener than the average for their age but the researchers stopped short of blaming delinquency on movies, pointing out that movies are only one strand in the experience that goes into delinquency. Films may have quite different effects on different children. 'The effect, they said, is "specific for a given child and a given movie".

American Academy of Pediatrics (AAP) suggests the parents to limit their children from watching television not more than one or two hours a day and not let them to watch themselves because for the growing brain of the children, when it is bombarded with lots of stimulations, it disturb their capability to learn focus well. AAP suggests that parents should watch over the children while they are watching the television especially the types of the cartoon movie. Dr Dimitri Christakis, the Director of Children Medical Centre from Washington University and Angelina Lilard with Peterson Jenifer, the researchers and also the journal writer said that the main core of the research and other researches that what do the children watch is same as how much do they watch. It is not to turn of the television but to change the channel and choose the suitable movie for the children. Beside that, by watching television in nine minutes, it will give negative effect for children executive brain and affect the brain function in short period. The point tends to determine about the limitation of what they watch not about how many hours of watching.

Knowing the result of the observation, the role of the parents to accompany the children to watch the movie is needed. The parents should choose the best and suitable programs to be watched by the children, calculate and limit the time to watch so that the children can study their school lesson as well as watch the movie. It is suggested here to watch educated movie program so that while watching that the children also gaining the 
knowledge through their parents's direction. It is better for the parents to do other educated activities to their children such as reading books - to know other information or to gain other science, fishing - to learn how to be patient to wait for something beside teach how to fish well or to introduce about the sea or lake, gardening - to teach how to plant the trees or flowers beside knowing that by gardening, we produce a lot of Oxygen, cleaning the house - to teach about how to live in healthy beside teaching the to be independent children for the future and many more activities. One thing should not be forgotten here is that the parents should teach their children about religion values so that they will now which thing is bad and good.

\section{CONCLUSION}

Literature gives many effects to people. Pleasure, life lesson, moral message are also given. Movie is one of the interesting media to learn something (the plot of life, the characteristics, the problem and also problem solving). It is really helpful for those who can not learn well by doing such an usual activity at school. School can not control the students for a day even the teachers as educators have the obligation to do it. Here, the parents take the whole control to educate the children. It is many things to do here. In this case, related to this writing, the parents have a duty to direct the children to choose their program in watching television especially in watching movie by seeing the types of movie can direct their brain to think. Children under age should be accompanied by the children so that they can find the educated movie which can help themselves to be good and not do negative thing out there. A lot of incidents had happened out there just because of movie effect such as rudeness, sexual harassments or other worst things. Therefore, to control the children's attitude the parents' biggest role is significant needed.

From the explanation above, there are lots of lesson teaching to people especially for parents or educators or other adult. From the learning, some suggestions come up to be paid attention. These are :

a. The parents should choose the best and suitable programs to be watched by the children, calculate and limit the time to watch so that the children can study their school lesson as well as watch the movie.

b. It is suggested here to watch educated movie program so that while watching that the children also gaining the knowledge through their parents' direction for example ; reading books, fishing, gardening or cleaning the house.

c. The parents should teach their children about religion values as the anticipation for the penetration of the bad influence. 


\section{References}

Amini Mukti. 2008. Mengembangkan Perkembangan Majemuk. Diakses tgl 14 December 2011 jam 15:30 dari http://muktiamini.blogdpot.com/2008/04.Mengebangkan -Kecerdasan-Majemuk.html

Bancroft Dir. Tony \& Cook Barry. 1998. Mulan. USA : Disney

Bancroft Dir. Tony \& Cook Barry . Perf. Ming-Na, Salonga Lea, and Murphy Eddie. 1998. Mulan. USA : Walt Disney Home Video

Best, J. W. 1977. Research in Education ( $3^{\text {rd }}$ Ed). New Jersey : Prentice Hall, Inc. Englewood Cliffs

Bodgan R \& Bikklen S. 1982. Qualitative Research for Education; An Introduction to Theory and Methods $2^{\text {nd }}$ edition. Boston : Allyn \& Bacon, Inc

Clements Dir. Ron \& Musker John. : 1992 Aladdin. USA : Disney

Gabriel Dir. Mike \& Goldberg Eric. 1955. Pocahontas. USA : Disney

Gabriel Dir. Mike \& Goldberg Eric. Bedard Perf. Irene, Kuhn Judy, and Gibson Mel. 1995. Pocahantas. USA : Walt Disney Home Video (http://www.dailycampus.

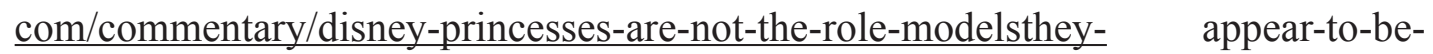
1.1080977)

Geronimi Dir. Clyde \& Jackson Wilfred. 1950. Cinderella. USA : Disney

"History." Walt Disney Animation Studios. N.p., n.d. Web. 10 Jun 2010. <http://www. disneyanimation.com/aboutus/history.html $>$.

Geronimi Dir, Clyde. 1957. Sleeping Beauty . USA :Disney

Grimm Whilhem \& Grimm Jacob, 1937. Snow White and The Seven Dwarves. USA : Disney Film (http://www.awn.com/mag/issue3.4/3.4pages/3.4kleinmulannotmp. $\underline{\mathrm{html}})$

Handayani. 2006. Contoh Karangan Narasi untuk Anak. Diakses tgl 7 Januari 2012, jam 19.00 dari : http://blog.tp.ac.id/tag/contoh-karangan-narasi-untuk-anak$\underline{\text { tk\#ixzz1OSGmLp7 }}$

Hefner Veronika. 2011. Dissertation Submitted in Partial Fulfillment of the Requirements for the Degree of Doctor of Philosophy in Speech Communication in the Graduate College of the University of Illinois at Urbana-Champaign

KPAI. 2008. Kartun Negatif. Diakses tgl 23 Januari 2012, jam 20.00 dari : http://blog.tp.ac. id/K O M P A S-K P A I/2008.com

Klein, Andy. “Disney's Mulan: A More Modern Heroine. Animation World Magazine July 1998: n. pag. Web. 10 Jun 2010. <http://www.awn.com/mag/issue3.4/3.4pages/3.4klei nmulannotmp.html $>$. 
Maccoby E. Eleanor. 1984. Development During Middle Childhood : The Years from Six to Twelve. (National Research Council (US) Panel to Review the Status of Basic Research on School- Age Children: Washington D.C : National Academic Press Simpson, J. A. 1989. Oxford English Dictionary. New York : Oxford Uni Press.

Stone. 1988. Cultural Perspective on Romantic Love. USA : Harvard

Tanner, L R. 2003. Images of Gender, Race, Age and Sexual Orientation in Disney Feature Length Animated Films. Journal of Feminist Family Therapy, Vol. 15(4) 2003. http:// www.haworthpress.com/web/JFFT.. The Haworth Press,Inc

Welleck Rene \& Warren Austin. 1948. Theory of Literature. New York, USA : Harcourt, Brace and Company

Yerby Amanda , Baron Samantha \& Lee Youjin . History of Animation Assignment 1, Part 4 Website Collaborative Content 